\title{
Fabrication of Ni-NiO Foams by Powder Metallurgy Technique and Study of Bulk Crushing Strength
}

\author{
Bappi Sarker ${ }^{1}$, Md. Arafat Rahman ${ }^{1, *}$, \\ Md. Mizanur Rahman ${ }^{1}$ and Md. Saiful Islam ${ }^{2}$ \\ ${ }^{I}$ Department of Mechanical Engineering, Chittagong University of Engineering and Technology, \\ Chittagong, Bangladesh \\ ${ }^{2}$ Department of Glass and Ceramic Engineering, Bangladesh University of Engineering and Technology, \\ Dhaka, Bangladesh
}

('Corresponding author's e-mail: arafat@cuet.ac.bd)

Received: 5 April 2021, Revised: 6 June 2021, Accepted: 9 June 2021

\begin{abstract}
Despite the importance of Nickel Oxide (NiO) in diverse functional applications, very little information is available on the mechanical properties of bulk or porous $\mathrm{NiO}$ or, mostly unnoticed. In this study, porous $\mathrm{Ni}-\mathrm{NiO}$ foam was synthesized using space holding-powder metallurgy and sintering methods to produce opened-cell structure with macrogravel and Neolamarckia cadamba (Cadamba flower) like surface morphology. Four different types of porous $\mathrm{Ni}-\mathrm{NiO}$ with different pore diameter of $35.65 \pm 12.77,36.10 \pm 8.85,68.20 \pm 7.36$ and $62.45 \pm 17.48 \mu \mathrm{m}$ were fabricated for evaluating the effect of porosity on the mechanical properties of bulk porous $\mathrm{Ni}-\mathrm{NiO}$ foam. The mechanical properties such as bulk crushing force of as synthesized Ni-NiO foam with various porosities such as 20.55, $27.35,27.85$ and $28.82 \%$ exhibited the average crushing load of $115.40,39.95,138.10$ and $151.20 \mathrm{~N}$, respectively. This study suggests that crushing load of $\mathrm{Ni}-\mathrm{NiO}$ foam is not only depending on the porosity but also on the sintering temperature and crystallite sizes of $\mathrm{NiO}$.
\end{abstract}

Keywords: Compressive load, Foam, Pore distribution, Sintering, Nickel oxide

\section{Introduction}

Cellular metals and metallic foams are metals with pores deliberately integrated in their structure. Due to their unique properties metal foams are used as an attractive material [1]. However, these materials are usually exposed to various mechanical loading stresses. Therefore, it is needed to understand how these porous structures behave under these mechanical stresses to design materials that show adequate properties for the required application [2,3]. There are several metal foam studied [4-10] for their uniqueness features such as exceptional uniformity, light weight, high porosity, intrinsic strength, corrosion resistance and good electrical and thermal conductivity. However, most of the cases mechanical properties of respected metal oxides (MOs) of these metals were ignored. In the past few decades, porous $\mathrm{NiO}$ foams attracted increasing attention in numerous functional applications such as electrodes of supercapacitior [11-13], gas sensors [14-16], an electrode of lithium-ion batteries (LIBs) [17-20], electrocatalyst for electrochemical water splitting application [21-23], and automotive glass [24]. However, despite the significant importance of $\mathrm{NiO}$ in the diverse functional applications, surprisingly no systematic investigation on the mechanical properties of bulk or porous $\mathrm{NiO}$ has been reported. Therefore, the important and extensive opportunities and need for this porous $\mathrm{NiO}$ foam in the field of energy and various industries are illustrative of the imperative driving forces for understanding the effect of structural porosity on the mechanical properties. It is noted that a deep understanding of mechanical properties and reliability of bulk porous $\mathrm{NiO}$ is necessary even in cases where it is used as functional materials such as electrodes of various energy storage systems. Riley et al. investigated the mechanical [25] and electrochemical properties [26] of electrodes of lithium ion batteries(LIBs) and indicated that the enhanced electrochemical performance was found to be a result from the $50 \%$ increase in hardness of electrode materials. Rahman et al. studied the nanogravel structured Ni-NiO foam as electrode for LIBs and indicated that better discharge capacity was observed due to increase in hardness of anode materials $[19,20]$. Hence, not only the electrochemical stability is essential for functional applications but also the mechanical stability of Ni-NiO foam is essential as well. For an instance, the mechanical properties of 
porous $\mathrm{Ni}-\mathrm{NiO}$ foam should decrease when porosity is increased which led to improved electrochemical performances due to increase in surface area. In contrast, electrochemical performances decrease when decrease in porosity which led to mechanical stability under load-bearing conditions increases. Hence, an optimum combination porosity and mechanical property of porous $\mathrm{Ni}-\mathrm{NiO}$ foam is necessary depending on its application as functional materials.

In this study, authors fabricated macrogravel and Neolamarckia cadamba (Cadamba flower) structured macroporous $\mathrm{Ni}-\mathrm{NiO}$ foam using powder metallurgy technique and space holding material. The porous characteristics, surface morphology, and crystallite sizes of as synthesized Ni-NiO foam is studied by using field emission scanning electron microscopy (FESEM), and X-ray Powder Diffraction (XRD). It is noted that as synthesized $\mathrm{Ni}-\mathrm{NiO}$ foams exhibited porosity of 20.55 to $28.82 \%$ and average bulk crushing strength of 0.25 to $0.97 \mathrm{MPa}$ which provides an understanding on some aspects of strength of $\mathrm{Ni}-\mathrm{NiO}$ foams for potential application as functional porous materials.

\section{Materials and methods}

\section{Sample preparation}

Figure 1 shows a schematic diagram of the fabrication process of porous $\mathrm{NiO}$ foam in this work. The process consists of 3 main steps such as i) mixing of Ni metal powder (purity $99.8 \%$ and maximum limit of impurity, Fe: $0.01 \%$, S: $0.001 \%$, C: $0.08 \%$, and O: $0.15 \%$, supplied by Sigma-Aldrich) and ammonium bicarbonate $\left(\mathrm{NH}_{4} \mathrm{HCO}_{3}\right)$ (purity $98.5 \%$ and maximum limit of impurity non-volatile matter: $0.01 \%, \mathrm{Cl}: 0.005 \%, \mathrm{SO}_{4}: 0.01 \%$, Fe: $0.002 \%$, and $\mathrm{Pb}: 0.0005 \%$, supplied by Sigma-Aldrich) as a space holder (SH) by using ball milling machine $(2 \mathrm{~h}$ at $100 \mathrm{rpm}$ with $5: 1$ ball to mixture ratio) having composition of $\mathrm{Ni}_{70} \mathrm{SH}_{30}$ and $\mathrm{Ni}_{50} \mathrm{SH}_{50}$ (wt\% hereafter), ii) compaction of $\mathrm{Ni}$ powder and space holder by using universal testing machine (UTM) to make green compacted samples at $250 \mathrm{MPa}, \mathrm{A}$ die punch assembly with dimension of $50 \times 50 \times 50 \mathrm{~mm}^{3}$ with a hole of $15 \mathrm{~mm}$ was used to proper compact of powder mixture, and iii) sintering of green compacted samples.

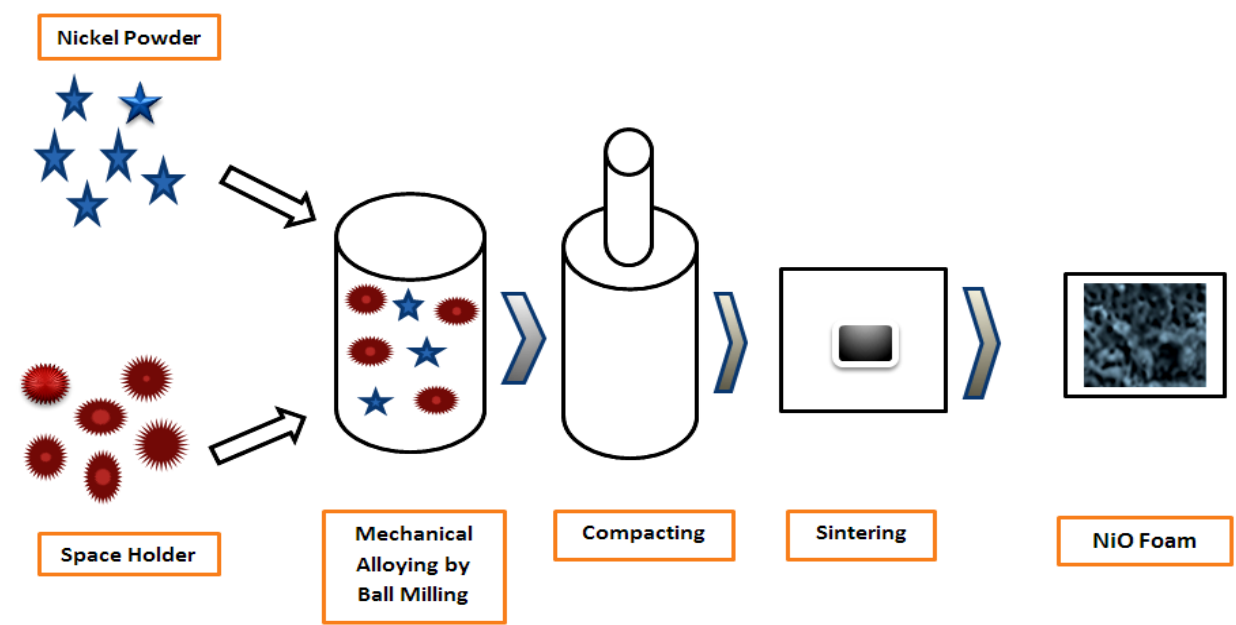

Figure 1 Schematic diagram of synthesis process of porous $\mathrm{Ni}-\mathrm{NiO}$ foam.

The sintering was carried out in a single step in a furnace (Nabertherm, Germany) at 600 and $700{ }^{\circ} \mathrm{C}$ and holding for $4 \mathrm{~h}$; thereafter rested in furnace for cooling.

\section{Characterization}

The morphologies of the as sintered $\mathrm{Ni}_{70} \mathrm{SH}_{30}$ and $\mathrm{Ni}_{50} \mathrm{SH}_{50}$ samples were examined with a scanning electron microscope (JSM 7600F, JEOL-Japan). The X-ray diffraction patterns of the samples were obtained by using $\mathrm{Cu} \mathrm{K} \alpha$ as the radiation source (Empyrean, PANalytical-Netherlands). The diffraction patterns were recorded over a $2 \theta$ range from 10 to $80^{\circ}$ at a step size of $0.01^{\circ}$.

\section{Bulk crushing test}

Finally, the sintered 7 to $10 \mathrm{Ni}_{70} \mathrm{SH}_{30}$ and $\mathrm{Ni}_{50} \mathrm{SH}_{50}$ samples with $40.00 \mathrm{~mm}$ length and $14.10 \mathrm{~mm}$ diameter were subjected to bulk compressive strength test and the average value was recorded. 


\section{Results and discussions}

\section{Characterization of porous $\mathrm{Ni}-\mathrm{NiO}$ foam}

Figure 2 compares the XRD patterns of pure $\mathrm{Ni}$ powder and as sintered $\mathrm{Ni}_{70} \mathrm{SH}_{30}$ and $\mathrm{Ni}_{50} \mathrm{SH}_{50}$, samples at 600 and $700{ }^{\circ} \mathrm{C}$. It is noted that there is no $\mathrm{NiO}$ peak observed for the as-received Ni powder. However, there is a noticeable similarity between XRD pattern of samples $\mathrm{Ni}_{70} \mathrm{SH}_{30}$ and $\mathrm{Ni}_{50} \mathrm{SH}_{50}$ sintered at 600 and $700{ }^{\circ} \mathrm{C}$. The pure Ni powder and samples $\mathrm{Ni}_{70} \mathrm{SH}_{30}$ and $\mathrm{Ni}_{50} \mathrm{SH}_{50}$ sintered at 600 and $700{ }^{\circ} \mathrm{C}$ exhibits typical diffraction peaks located at $2 \theta=44.51^{\circ}, 51.86^{\circ}$ and $76.39^{\circ}$ which can be attributed to $\mathrm{Ni}$ (111), (200) and (220), respectively. After sintering process of all samples at 600 and $700{ }^{\circ} \mathrm{C}$ in the air, 4 additional peaks were observed at $2 \theta=37.21^{\circ}, 44.51^{\circ}, 51.86^{\circ}$ and $76.38^{\circ}$. These peaks can be indexed to the (101), (110), (200) and (110) planes of a face centered cubic (FCC) NiO, respectively. The crystallite sizes of the Ni-NiO foam were calculated using the Scherrer equation as $\mathrm{D}=0.94 \lambda /(\mathrm{B} \cos \theta)$, where $\mathrm{D}$ is the average dimension of crystallites, $\lambda$ is the wavelength of $\mathrm{X}$-ray and $\mathrm{B}$ is the full width at half maximum of a reflection located at $2 \theta$ [27].

The average crystallite sizes of the metallic Ni before and after sintering in air are approximately 94.30, 95.65 and $101.40 \mathrm{~nm}$ of $\mathrm{Ni}(111)$, (200) and (220) faces, respectively. In addition, the average crystallite sizes of the $\mathrm{NiO}$ of samples $\mathrm{Ni}_{50} \mathrm{SH}_{50}$ and $\mathrm{Ni}_{70} \mathrm{SH}_{30}$ after sintering in the air for $4 \mathrm{~h}$ at $600{ }^{\circ} \mathrm{C}$ is observed 29.01 and $20.84 \mathrm{~nm}$, respectively.

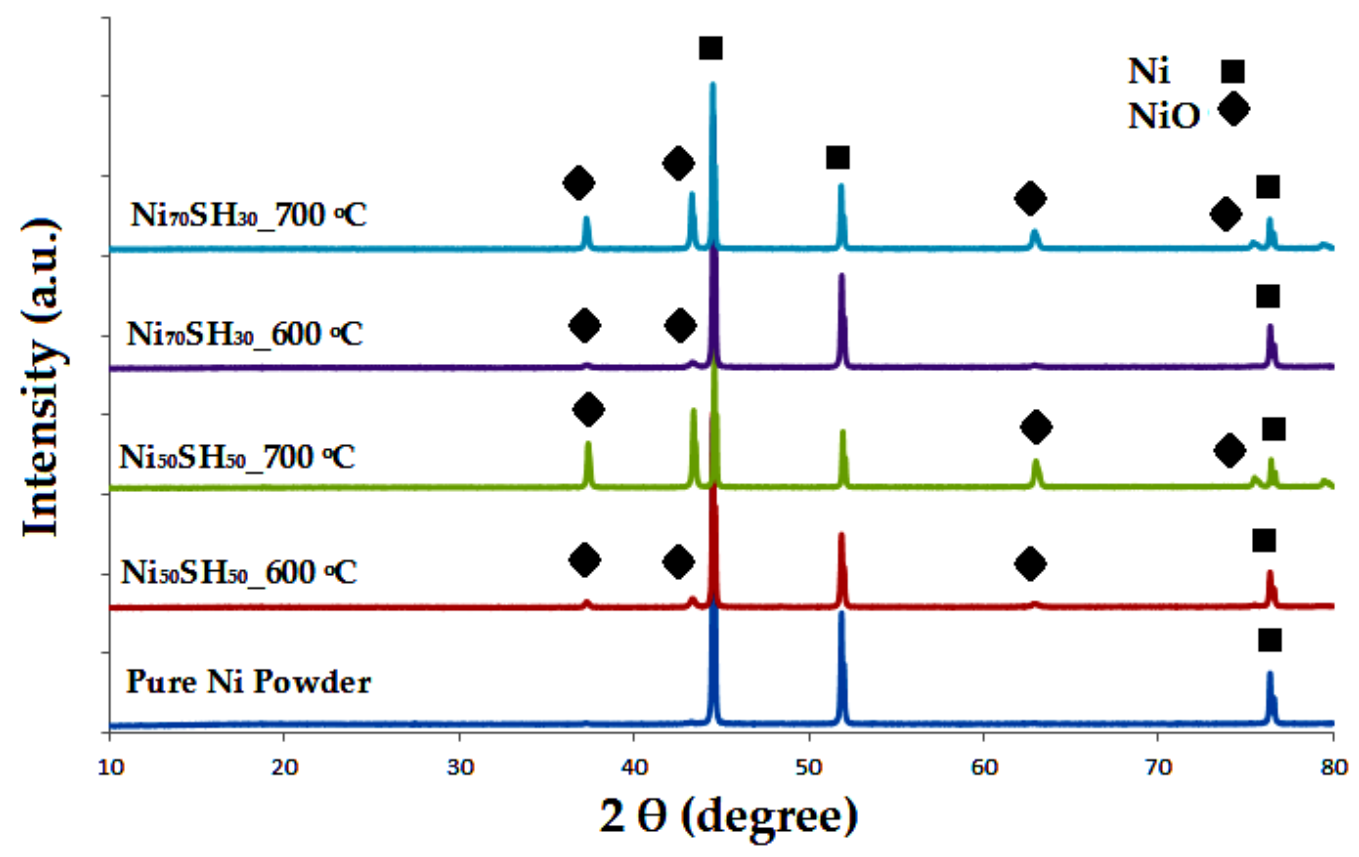

Figure 2 XRD patterns of the pure Ni powder and the porous $\mathrm{Ni}_{70} \mathrm{SH}_{30}$ and $\mathrm{Ni}_{50} \mathrm{SH}_{50}$ sintered at 600 and $700{ }^{\circ} \mathrm{C}$ for $4 \mathrm{~h}$.

However, the average crystallite sizes of the $\mathrm{NiO}$ of samples $\mathrm{Ni}_{50} \mathrm{SH}_{50}$ and $\mathrm{Ni}_{70} \mathrm{SH}_{30}$ are increased when sintered in air for $4 \mathrm{~h}$ at $700{ }^{\circ} \mathrm{C}$ and found to be 58.95 and $52.20 \mathrm{~nm}$, respectively. The increase in crystallite size with increasing sintering temperature can be attributed to thermally promoted crystallite growth $[28,29]$.

Figure 3 shows the low and high magnification images of porous $\mathrm{Ni}_{70} \mathrm{SH}_{30}$ foam at 600 and $700{ }^{\circ} \mathrm{C}$. It is noted that sintering necks between particles are clearly found from Figure 3(b). In addition, a thin oxide layer of $\mathrm{NiO}$ was left on the $\mathrm{Ni}$ surface due to a remarkable increase in temperature as shown in Figure 3(d). These types of surface morphology such as pores, metal to metal or metal oxides contact, and cracks all are responsible to change the internal stress distribution [30-32]. 

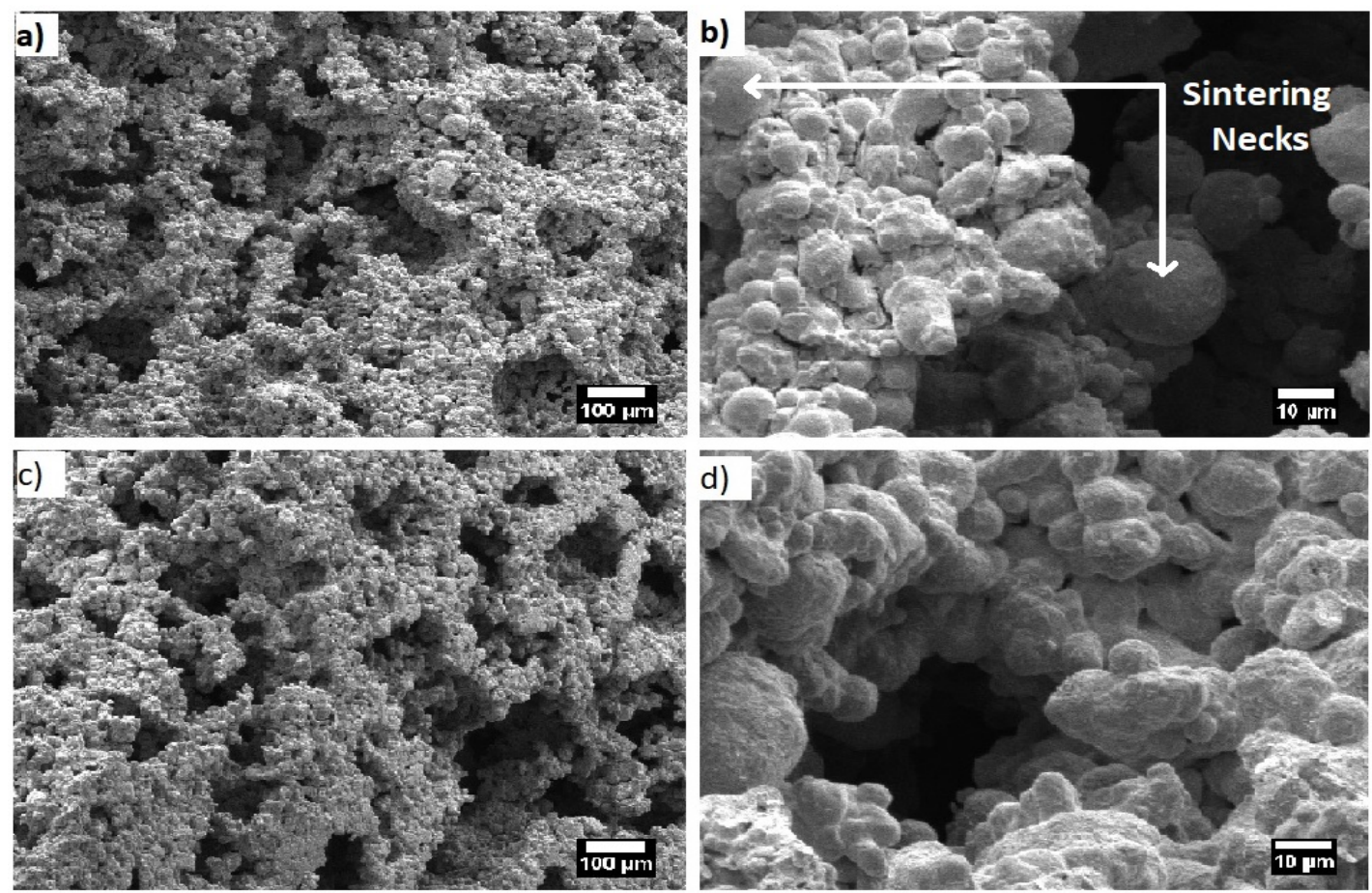

Figure 3 Low and high magnification SEM images of porous $\mathrm{Ni}_{70} \mathrm{SH}_{30}$ foam after sintering at (a, b) 600 ${ }^{\circ} \mathrm{C}$ and (c, d) $700{ }^{\circ} \mathrm{C}$.

Figure 4 shows the low and high magnification images of porous $\mathrm{Ni}_{50} \mathrm{SH}_{50}$ foam at 600 and $700{ }^{\circ} \mathrm{C}$. It is worthy to mention that the surface of a single nickel particle which exhibits a nanoflake of Neolamarckia cadamba (Cadamba flower) like surface morphology of $\mathrm{NiO}$ as shown in Figure 4(b) at $600{ }^{\circ} \mathrm{C}$. This type of surface morphology of $\mathrm{NiO}$ can provide enormous space for diffusion of electrolyte ions of electrodes of supercapacitor [33]. However, uniformly distributed gravels of $\mathrm{NiO}$ surface morphology exhibited as shown in Figure 4(d) when sintering temperature increased to 700 ${ }^{\circ} \mathrm{C}$. The main reason for differences in morphology of $\mathrm{Ni}-\mathrm{NiO}$ foam at high temperature is basically generation of different thermal stress [31].
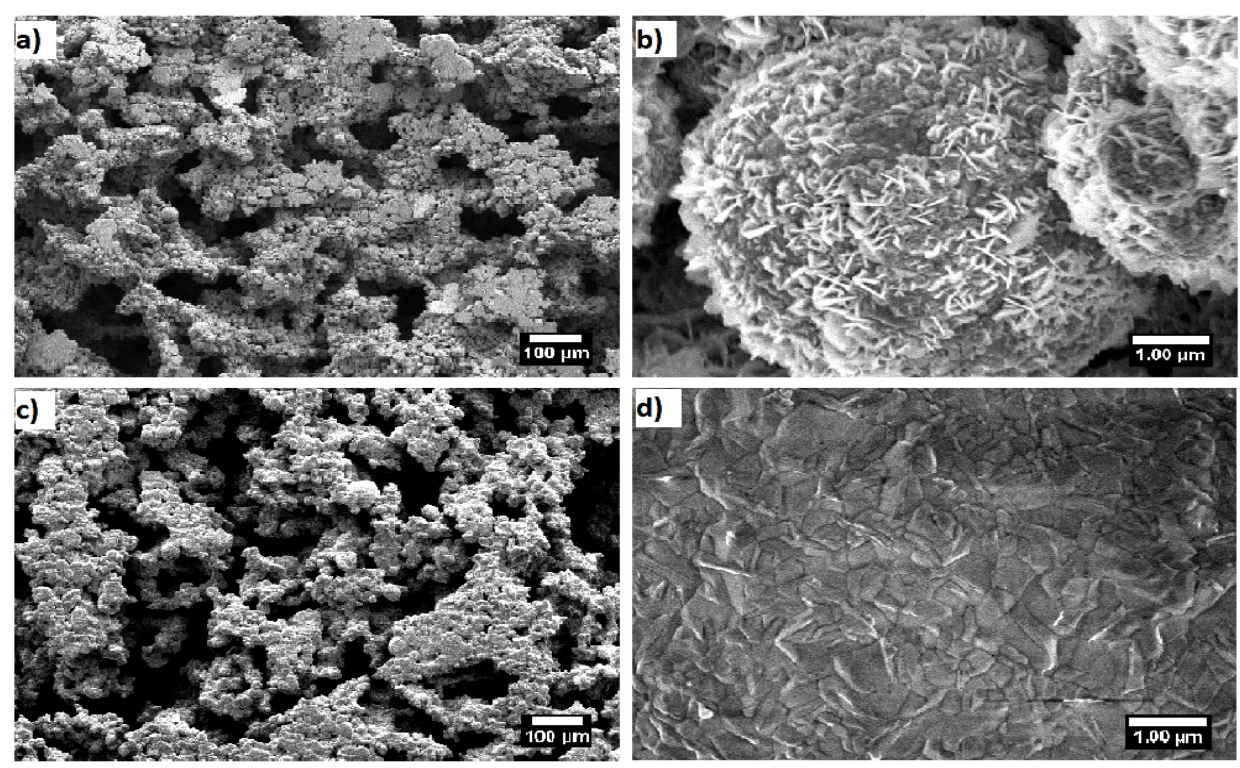

Figure 4 Low and high magnification SEM images of porous $\mathrm{Ni}_{50} \mathrm{SH}_{50}$ foam after sintering at (a, b) 600 ${ }^{\circ} \mathrm{C}$ and (c, d) $700{ }^{\circ} \mathrm{C}$. 
Figure 5 shows the frequency distribution of pore diameter of porous Ni-NiO foams at 600 and 700 ${ }^{\circ} \mathrm{C}$. It should be noted that the pore distribution graphs were generated from the measurements of pore diameter of SEM images by using Image $\mathrm{J}$ software. The mean pore diameter of porous $\mathrm{Ni}_{70} \mathrm{SH}_{30}$ foam is obtained $35.65 \pm 12.77 \mu \mathrm{m}$ (Figure 5(a)) at $600{ }^{\circ} \mathrm{C}$ and slightly increased to $36.10 \pm 8.85 \mu \mathrm{m}$ (Figure 5(b)) after sintering at $700{ }^{\circ} \mathrm{C}$ in air. This phenomenon is ascribed to the enlargement of pores during sintering. However, the mean pore diameter of porous $\mathrm{Ni}_{50} \mathrm{SH}_{50}$ foam is $68.20 \pm 7.36 \mu \mathrm{m}$ (Figure $\mathbf{5 ( c )}$ ) at $600{ }^{\circ} \mathrm{C}$ and decreased to $62.45 \pm 17.48 \mu \mathrm{m}$ (Figure 5(d)) after sintering $700{ }^{\circ} \mathrm{C}$ in air. It is worthy to mention that the mean pore diameter of porous $\mathrm{Ni}_{50} \mathrm{SH}_{50}$ foam should be increased due more evaporation of space holding materials. However, similar phenomenon observed for other ceramic materials which can be ascribed to the densification of the body promoting partial removal of porosity at high temperatures [34,35].
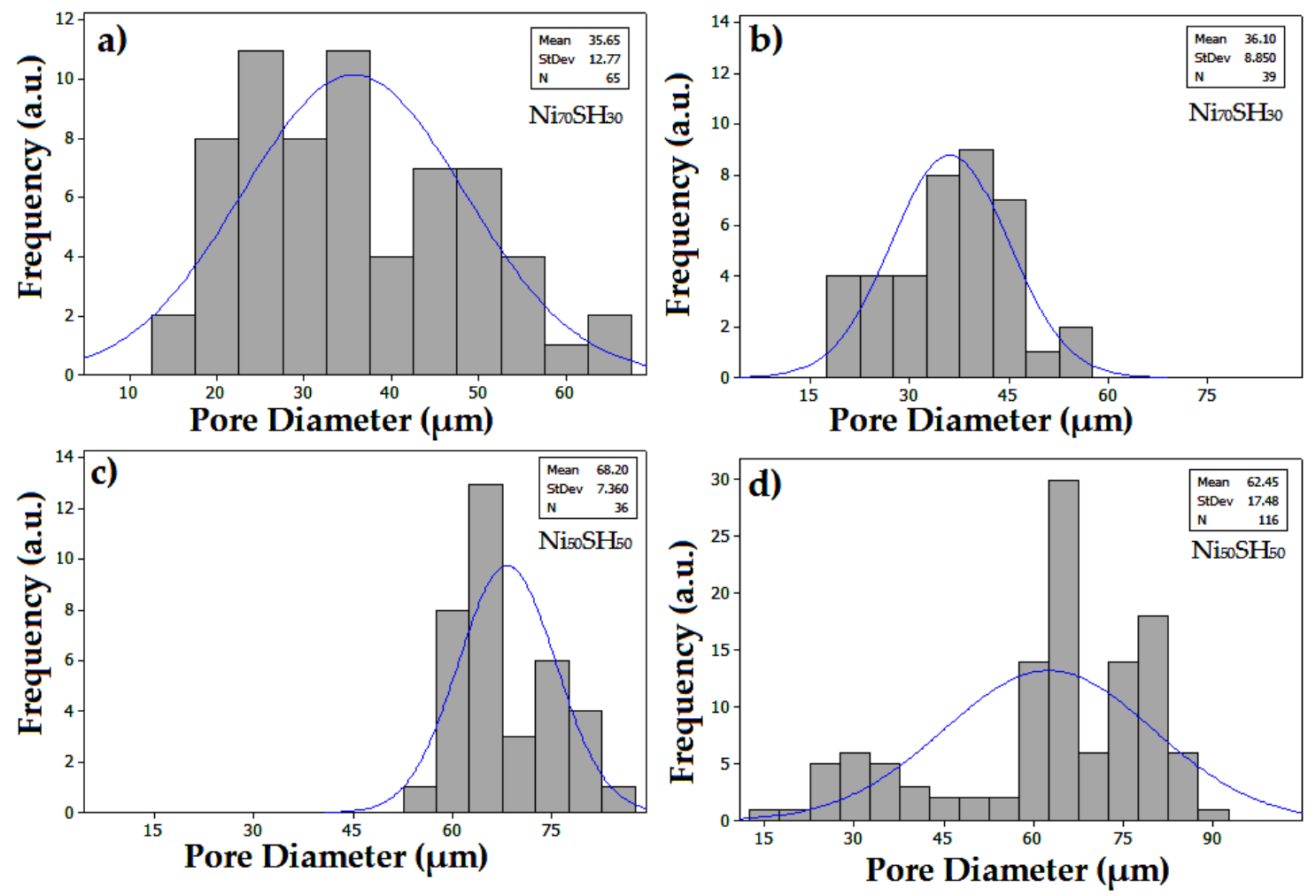

Figure 5 Frequency distribution of pore diameter of porous $\mathrm{Ni}-\mathrm{NiO}$ foam after sintering $\mathrm{Ni}_{70} \mathrm{SH}_{30}$ and $\mathrm{Ni}_{50} \mathrm{SH}_{50}$ at $(\mathbf{a}, \mathbf{c}) 600^{\circ} \mathrm{C}$ and $(\mathbf{b}, \mathbf{d}) 700^{\circ} \mathrm{C}$.

Figure 6 shows the SEM images of variation of porosity of $\mathrm{Ni}_{70} \mathrm{SH}_{30}$ and $\mathrm{Ni}_{50} \mathrm{SH}_{50}$ foam sintering at 600 and $700{ }^{\circ} \mathrm{C}$ during porosity analysis through Image $J$ software. It is noted that the porosity of $\mathrm{Ni}_{50} \mathrm{SH}_{50}$ foam increased from 20.55 to $27.35 \%$ when in sintering temperature increased $600{ }^{\circ} \mathrm{C}$ (Figure 6(a)) to $700{ }^{\circ} \mathrm{C}$ (Figure 6(b)). The similar phenomenon was observed for the $\mathrm{Ni}_{70} \mathrm{SH}_{30}$ foam where porosity slightly increased 27.85 to $28.82 \%$ when in sintering temperature increased $600{ }^{\circ} \mathrm{C}$ (Figure 6(c)) to $700{ }^{\circ} \mathrm{C}$ (Figure $6(\mathbf{d})$ ). This phenomenon ascribed to the more evaporation of space holding material due to increase in sintering temperature. It is noted that increasing sintering temperature increase the pore diameter of samples but decrease the porosity of sintered samples due to sintering linear shrinkage [36-39]. However, the porosity and pore diameter of $\mathrm{Ni}_{70} \mathrm{SH}_{30}$ and $\mathrm{Ni}_{50} \mathrm{SH}_{50}$ foam is increased due to the temperature of sintering linear shrinkage of nickel/oxides above $800{ }^{\circ} \mathrm{C}$ [40-43]. 


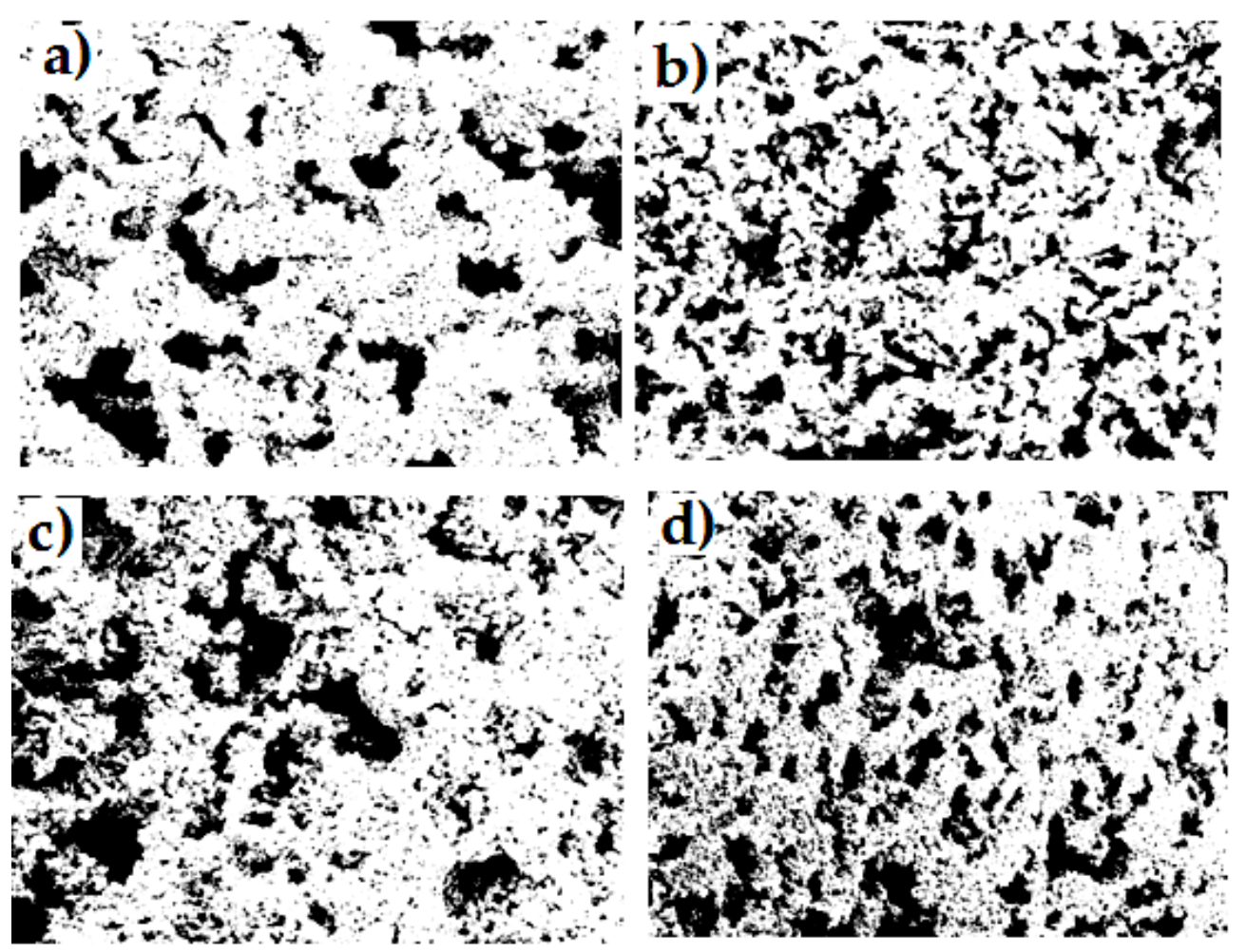

Figure $6 \mathrm{SEM}$ images of porous Ni-NiO foam during porosity analysis through Image $\mathrm{J}$ software: sintering of $(\mathbf{a}, \mathbf{b}) \mathrm{Ni}_{50} \mathrm{SH}_{50}$ and $(\mathbf{c}, \mathbf{d}) \mathrm{Ni}_{70} \mathrm{SH}_{30}$ at 600 and $700{ }^{\circ} \mathrm{C}$. (Black spot is Pore and White spot is Oxide).

\section{Bulk crushing strength of porous Ni-NiO foam}

The mechanical strength of porous material is an important parameter that provides a measure of the mechanical reliability and this depends on the material resistance to the bulk crushing [44]. It is noted that intense investigation is necessary to understand the bulk crushing strength (BCS) of bulk solid porous materials before industrial applications [45-48]. In this BCS tests, bulk cylindrical shaped $\mathrm{Ni}_{70} \mathrm{SH}_{30}$ and $\mathrm{Ni}_{50} \mathrm{SH}_{50}$ foams with $40.00 \mathrm{~mm}$ in length and $14.10 \mathrm{~mm}$ in diameter were quasi-statically compressed as shown in Figure 7.
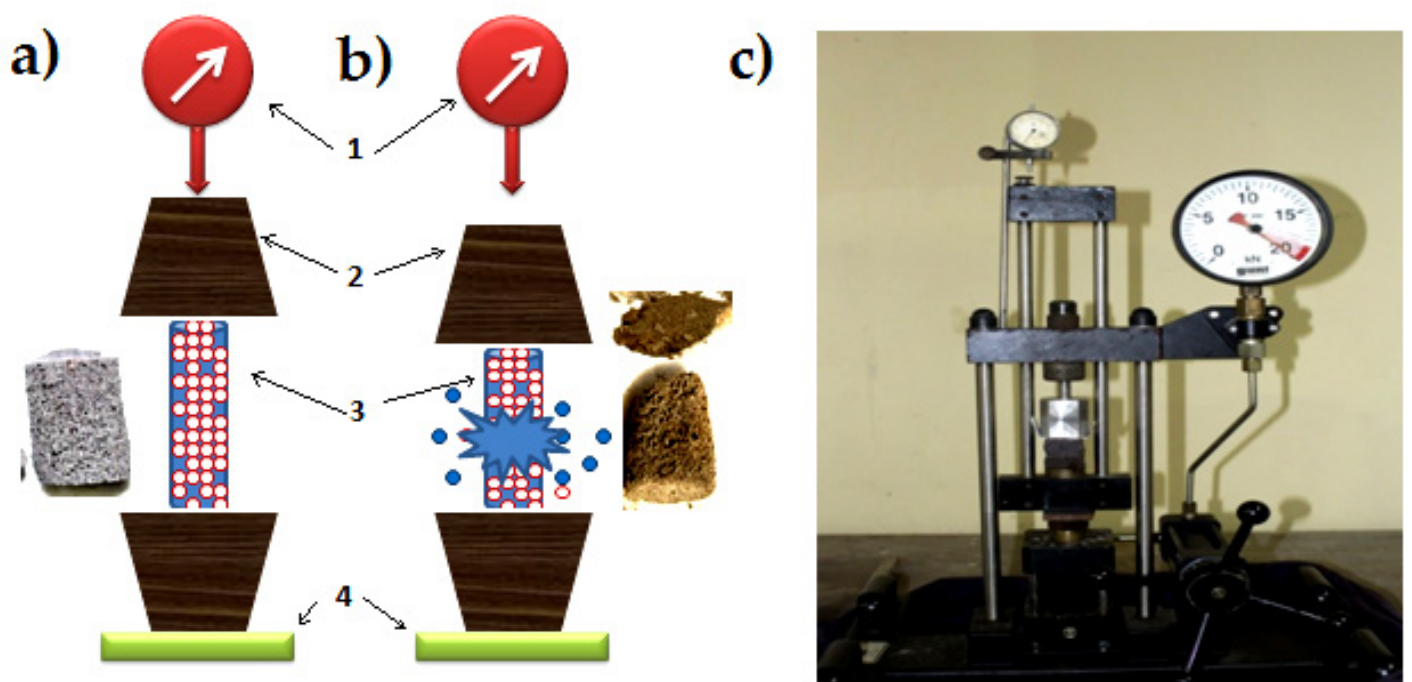

Figure 7 Schematic representation of crushing strength test: a) assemble for bulk crushing test, b) immediate after bulk crushing test, and c) UTM for crushing test. (Here numbers represent: 1-force indicator, 2-moveable cross head, 3-samples, 4-fixed table). 
Figure 8 shows the comparison of bulk crushing force (Figure 8(a)) and crushing strength (Figure 8(b)) of $\mathrm{Ni}_{70} \mathrm{SH}_{30}$ and $\mathrm{Ni}_{50} \mathrm{SH}_{50}$ foam after sintering at 600 and $700{ }^{\circ} \mathrm{C}$. It is worthy to mention that the uniaxial compressive load was applied to the samples until the rupture moment takes place. The quality of the BCS of $\mathrm{Ni}_{70} \mathrm{SH}_{30}$ foam is improved with the increase in sintering temperature, and the $\mathrm{Ni}_{70} \mathrm{SH}_{30}$ foam is exhibited less rigid with the decrease in temperature. The average crushing load of $\mathrm{Ni}_{70} \mathrm{SH}_{30}$ foam with porosity increased to 27.85 to $28.82 \%$ is observed 138.10 to $151.20 \mathrm{~N}$ when sintering temperature was increased from 600 to $700{ }^{\circ} \mathrm{C}$, respectively. In contrast, the average crushing load of $\mathrm{Ni}_{50} \mathrm{SH}_{50}$ foam with porosity increased to 20.55 to $27.35 \%$ is observed 115.40 to $39.95 \mathrm{~N}$ when sintering temperature was increased to 600 to $700{ }^{\circ} \mathrm{C}$, respectively. This dichotomy behavior of $\mathrm{Ni}_{70} \mathrm{SH}_{30}$ and $\mathrm{Ni}_{50} \mathrm{SH}_{50}$ foam can be ascribed to the stress concentration in less amount of $\mathrm{NiO}$ of $\mathrm{Ni}_{50} \mathrm{SH}_{50}$ foam compared to $\mathrm{Ni}_{70} \mathrm{SH}_{30}$ foam which led to promote failure under uniaxial compressive loading through introducing microcracks [49]. It is contrary to popular believed that the highly porous material with high porosity is weak and easy to break. However, the BCS of porous material depends on the size, number of pore, pore shape, and crystallinity of materials [50-53]. However, the average crystallite size of $\mathrm{NiO}$ of porous $\mathrm{Ni}_{50} \mathrm{SH}_{50}$ and $\mathrm{Ni}_{70} \mathrm{SH}_{30}$ foam is observed to be 58.95 and $52.20 \mathrm{~nm}$ (from Figure 2), respectively. Hence, small crystallite size of $\mathrm{NiO}$ of $\mathrm{Ni}_{70} \mathrm{SH}_{30}$ foam led high dense boundaries and increased the activity of grain and enhanced the mechanical property compared to the $\mathrm{NiO}$ of $\mathrm{Ni}_{50} \mathrm{SH}_{50}$ [54] .
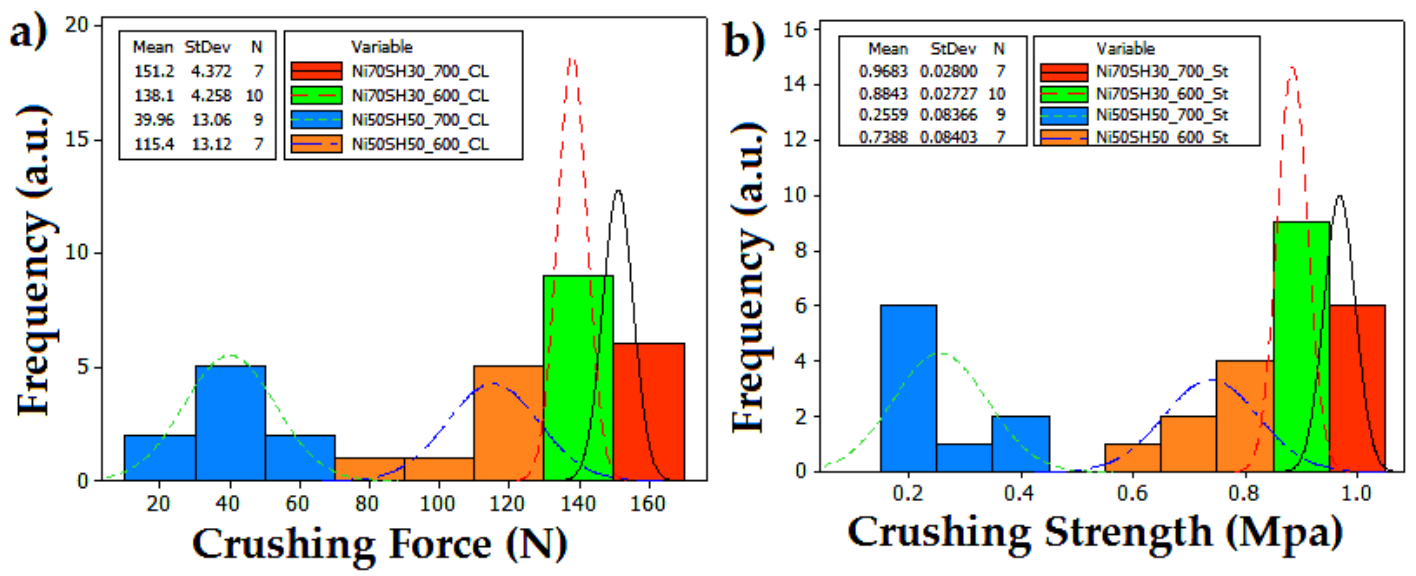

Figure 8 Frequency distribution of a) bulk crushing force and b) bulk crushing strength.

\section{Conclusions}

In summary, porous $\mathrm{Ni}-\mathrm{NiO}$ foams with $4^{\text {th }}$ types of pore diameters and porosities ranging from 20.55 to $28.82 \%$ were prepared using space holding-powder metallurgy and sintering methods at 600 $700{ }^{\circ} \mathrm{C}$ in air for $4 \mathrm{~h}$. The pore size and porosity can be altered through changing the composition of space holder and $\mathrm{Ni}$ powder, and sintering temperature. Four different types of porous Ni-NiO with different pore diameter of $35.65 \pm 12.77,36.10 \pm 8.85,68.20 \pm 7.36$ and $62.45 \pm 17.48 \mu \mathrm{m}$ were exhibited the average crushing load of $115.4,39.95,138.10$, and $151.20 \mathrm{~N}$, respectively. In addition, the bulk crushing strength of 4 different types of $\mathrm{Ni}-\mathrm{NiO}$ foam with porosity of $20.55,27.35,27.85$ and $28.82 \%$ were exhibited $0.25 \mathrm{MPa}, 0.74 \mathrm{MPa}, 0.88 \mathrm{MPa}$, and $0.96 \mathrm{MPa}$, respectively. It is noted that highest bulk crushing strength was observed to be $0.96 \mathrm{MPa}$ of $\mathrm{Ni}_{70} \mathrm{SH}_{30}$ with $28.82 \%$ of porosity which was sintered at $700{ }^{\circ} \mathrm{C}$.

\section{Acknowledgements}

The study was financially co-supported by Postgraduate Research Fund (M.Sc. Engineering) of Chittagong University of Engineering and Technology, Chittagong-4349, Bangladesh through titled of "Study of Mechanical Properties of Porous NiO" and Bangladesh Bureau of Educational Information \& Statistics (BANBEIS) through research grant No. PS20191251. 


\section{References}

[1] J Banhart and D Weaire. On the road again: Metal foams find favor. Phys. Today 2002; 55, 37-42.

[2] Y Yamada, C We, K Shimojima, M Mabuchi, M Nakamura, T Asahina, T Aizawa and K Higashi. Effects of cell geometry on the compressive properties of nickel foams. Mater. Trans. 2000; 41, 1136-8.

[3 VR Salvini, VC Pandolfelli and D Spinelli. Mechanical properties of porous ceramics. In: UB AlNaib (Ed.). Recent advances in porous ceramics. Intechopen, London. 2018, p. 171-99.

[4] XH Han, Q Wang, YG Park, C T'Joen, A Sommers and A Jacobi. A review of metal foam and metal matrix composites for heat exchangers and heat sinks. Heat Transf. Eng. 2012; 33, 991-1009.

[5] S Kim and CW Lee. A review on manufacturing and application of open-cell metal foam. Procedia Mater. Sci. 2014; 4, 305-9.

[6] A Kulshreshtha and S Dhakad. Preparation of metal foam by different methods: A review. Mater. Today: Proc. 2020; 26, 1784-90.

[7] A Changdar and SS Chakraborty. Laser processing of metal foam-A review. J. Manuf. Process. 2021; 61, 208-25.

[8] R Pandey, P Singh, M Khanna and Q Murtaza. Metal foam manufacturing, mechanical properties and its designing aspects: A Review. In: RM Singari, K Mathiyazhagan and H Kumar (Eds.). Advances in manufacturing and industrial engineering. Springer, Singapore. 2021, p. 761-70.

[9] Y Li, L Gong, B Ding, M Xu and Y Joshi. Thermal management of power electronics with liquid cooled metal foam heat sink. Int. J. Therm. Sci. 2021; 163, 106796.

[10] H Nakajima. Fabrication, properties and application of porous metals with directional pores. Prog. Mater. Sci. 2007; 52, 1091-73.

[11] F Cao, G Pan, X Xia, P Tang and H Chen. Synthesis of hierarchical porous NiO nanotube arrays for supercapacitor application. J. Power Sources .2014; 264, 161-7.

[12] YP Zeng, L Wang, Z Wang, J Xiao and H Wang. Facile synthesis of self-assembled porous NiO nanostructures and their application to supercapacitor electrodes. Mater. Today Commun. 2015; 5, 70-4.

[13] W Yiliang, B Chang, D Guan, K Pei, Z Chen, M Yang and X Dong. Preparation of nanospherical porous $\mathrm{NiO}$ by a hard template route and its supercapacitor application. Mater. Lett. 2014; 135, 172-5.

[14] C Su, L Zhang, Y Han, C Ren, B Li, T Wang, M Zeng, Y Su, N Hu, Z Zhou, Y Wang, Z Yang and $\mathrm{L} \mathrm{Xu}$. Glucose-assisted synthesis of hierarchical NiO-ZnO heterostructure with enhanced glycol gas sensing performance. Sens. Actuators B Chem. 2020; 329, 129167.

[15] P Gao, H Ji, Q Jia and Y Zhou. Porous $\mathrm{WO}_{3} \mathrm{NiO}$ thin films prepared by Sol-Gel method for selective acetone gas detection. In: Proceedings of the $14^{\text {th }}$ International Meeting on Chemical Sensors, Nuremberg, Germany. 2012, p. 746-9.

[16] P Manivasakan, P Ramasamy and J Kim. Reactive-template fabrication of porous NiO nanowires for electrocatalytic O2 evolution reaction. RSC Advances. 2015; 5, 33269-74.

[17] YB Mollamahale, Z Liu, Y Zhen, ZQ Tian, D Hosseini, L Chen and PK Shen. Simple fabrication of porous $\mathrm{NiO}$ nanoflowers: Growth mechanism, shape evolution and their application into Li-ion batteries. Int. J. Hydrog. Energ. 2017; 42, 7202-11.

[18] Z Sun, W Ai, J Liu, X Qi, Y Wang, J Zhu, H Zhange and T Yu. Facile fabrication of hierarchical $\mathrm{ZnCo} 2 \mathrm{O} 4 / \mathrm{NiO}$ core/shell nanowire arrays with improved lithium-ion battery performance. Nanoscale 2014; 6, 6563-8.

[19] MA Rahman and C Wen. Nanogravel structured $\mathrm{NiO} / \mathrm{Ni}$ foam as electrode for high-performance lithium-ion batteries. Ionics 2015; 21, 2709-23.

[20] MA Rahman and C Wen. A study of the capacity fade of porous $\mathrm{NiO} / \mathrm{Ni}$ foam as negative electrode for lithium-ion batteries. Ionics. 2016; 22, 173-84.

[21] J Rong, T Zhang, F Qiu and M Chen. Structural evolution of hierarchical porous NiO/Al2O3 composites and their application for removal of dyes by adsorption. Korean J. Chem. Eng. 2016; 34, 41-53.

[22] P Babar, A Lokhande, MG Gang, B Pawar, S Pawar and J Kim. Thermally oxidized porous NiO as an efficient oxygen evolution reaction (OER) electrocatalyst for electrochemical water splitting application. J. Ind. Eng. Chem. 2017; 60, 493-7.

[23] S Sun, X Jin, B Cong, X Zhou, W Hong and G Chen. Construction of porous nanoscale NiO/NiCo2O4 heterostructure for highly enhanced electrocatalytic oxygen evolution activity. J. Catal. 2019; 379, 19.

[24] WC Lee, EC Choi, J Boo and B Hong. A study on characterization of nano-porous NiO thin film to improve electrical and optical properties for application to automotive glass. Thin Solid Films 2017; 641, 28-33. 
[25] LA Riley, AS Cavanagh, SM George, SH Lee and AC Dillon. Improved mechanical integrity of ALD-coated composite electrodes for Li-ion batteries. Electrochem. Solid-State Lett. 2010; 14, A29.

[26] Riley LA, Lee S-H, Gedvilias L and Dillon AC. Optimization of MoO3 nanoparticles as negativeelectrode material in high-energy lithiumion batteries. J. Power Sources. 2010; 195, 588-92.

[27] YB Zhang, ZF Zhu, WJ Zhang, YL Zhang, H Liu, GH Chen and Y Wang. Synthesis of nanoflower precursors in two-phase system via microwave-assisted hydrothermal method and their in situ thermal convention to NiO. J. Nano Res. Trans. Tech. Publ. 2012; 20, 43-52.

[28] AR West. Solid state chemistry and its applications, $2^{\text {nd }}$ edition, student edition. John Wiley \& Sons, Ltd, New Jersey. 2014, p. 584.

[29] S Haq, W Rehman, M Waseem, R Javed and M Shahid. Effect of heating on the structural and optical properties of TiO 2 nanoparticles: Antibacterial activity. Appl. Nanosci. 2018; 8, 11-8.

[30] MA Rahman, X Zhu and C Wen. Fabrication of nanoporous Ni by chemical dealloying Al from NiAl alloys for lithium-ion batteries. Int. J. Electrochem. Sci. 2015; 10, 3767-83.

[31] DR Clarke. Stress generation during high-temperature oxidation of metallic alloys. Curr. Opin. Solid State Mater. Sci. 2002; 6, 237-44.

[32] Y Yamada, T Banno, ZK Xie, YC Li and CE Wen. Preparation and characterisation of open-cell microporous nickel. Mater. Sci. Forum: Trans. Tech. Publ. 2007; 539-543, 1833-8.

[33] K Malaie, M Ganjali, T Alizadeh and P Norouzi. Simple electrochemical preparation of nanoflakelike copper oxide on $\mathrm{Cu}$-plated nickel foam for supercapacitor electrodes with high areal capacitance. J. Mater. Sci. Mater. Electron. 2017; 28,14631-7.

[34] JGD Nemaleu, RC Kaze, S Tome, T Alomayri, H Assaedi, E Kamseu, UC Melo and VM Sglavo. Powdered banana peel in calcined halloysite replacement on the setting times and engineering properties on the geopolymer binders. Constr. Build. Mater. 2021; 279, 122480.

[35] SE Bendaoudi, M Bounazef and A Djeffal. The effect of sintering temperature on the porosity and compressive strength of corundum. J. Mech. Behav. Mater. 2018; 27.

[36] M Mouiya, A Bouazizi, A Abourriche, YEl Khessaimi, A Benhammou, Y Taha, M Oumam, Y Abouliatim, A Smith and H Hannache. Effect of sintering temperature on the microstructure and mechanical behavior of porous ceramics made from clay and banana peel powder. Results Mater. $2019 ; 4,100028$.

[37] YS Han, JB Li, B Chi and ZH Wen. The effect of sintering temperature on porous silica composite strength. J. Porous Mater. 2003; 10, 41-5.

[38] AHM Ariff, MAM Najib, SM Tahir, A As'Arry and N Mazlan. Effect of sintering temperature on the properties of porous $\mathrm{Al}_{2} \mathrm{O}_{3}-10 \mathrm{wt} \% \mathrm{RHA} / 10 \mathrm{wt} \% \mathrm{Al}$ composite. Adv. Mater. Process. Technol. 2020; 1-12, 417-28.

[39] KY Wang, HJ Wang, Y Zhou, Y Wu, G Li and YM Tian. Effect of sintering temperature on the microstructure and mechanical properties of low-cost light-weight proppant ceramics. IOP Conf. Ser. Mater. Sci. Eng. 2017; 230, 012022.

[40] Y Kharchenko, Z Blikharskyy, V Vira, B Vasyliv and V Podhurska. Study of nanostructural changes in a Ni-containing cermet material during reduction and oxidation at $600^{\circ} \mathrm{C}$. Appl. Nanosci. 2020; 10, 4535-43.

[41] Y Kharchenko, Z Blikharskyy, V Vira, B Vasyliv, VY Podhurska, A Kalynovskyy and V Korendiy. Nanostructural changes in a $\mathrm{Ni} / \mathrm{NiO}$ cermet during high-temperature reduction and reoxidation. In: O Fesenko and L Yatsenko (Eds.). Nanomaterials and nanocomposites, nanostructure surfaces, and their applications. Springer, New York, 2021, p. 219-29.

[42] U Betke, K Schelm, A Rodak and M Scheffler. Cellular Nickel-Yttria/Zirconia (Ni-YSZ) cermet foams: Manufacturing, microstructure and properties. Materials 2020; 13, 2437.

[43] S Watanabe, S Sukino, T Miyasaka, K Sato, K Yashiro, T Kawada and T Hashida. Influences of Ni content and porosity on mechanical properties of Ni-YSZ composites under solid oxide fuel cell operating conditions. J. Mater. Sci. 2020; 55, 8679-93.

[44] Y Li, D Wu, J Zhang, L Chang, D Wu, Z Fang and Y Shi. Measurement and statistics of single pellet mechanical strength of differently shaped catalysts. Powder Technol. 2000; 113, 176-84.

[45] Y Hiramatsu and Y Oka. Determination of the tensile strength of rock by a compression test of an irregular test piece. Int. J. Rock Mech. Min. Sci. Geomech. Abstr. 1966; 3, 89-90.

[46] S Griner, M Spilka and A Kania. Heterogenity of mechanical properties and fractures of Co-based metallic glass in a low temperature thermal activation process. J. Achiev. Mater. Manuf. Eng. 2014; 66, 53-60. 
[47] M Konieczny and B Szwed. Effect of processing parameters on the tensile behavior of laminated composites synthesized using titanium and aluminum foils. J. Achiev. Mater. Manuf. Eng. 2014; 66, 817.

[48] E David. Mechanical strength and reliability of the porous materials used as adsorbents/catalysts and the new development trends. Arch. Mater. Sci. Eng. 2015; 73, 5-17.

[49] D Liu, B Šavija, GE Smith, PE Flewitt, T Lowe and E Schlangen. Towards understanding the influence of porosity on mechanical and fracture behaviour of quasi-brittle materials: Experiments and modelling. Int. J. Fract. 2017; 205, 57-72.

[50] PSA Rahim, MS Shamsudin, NA Nazaruddin and R Muda. The effect of Nickel Oxide (NiO) compositions in consolidation of Silica-Nickel Oxide $\left(\mathrm{SiO}^{2}-\mathrm{NiO}\right)$ foams using replication method. $J$. Mech. Eng. 2017; 4, 63-72.

[51] R Coble and W Kingery. Effect of porosity on physical properties of sintered alumina. J. Am. Ceram. Soc. 1956; 39, 377-85.

[52] DV Prosvirnin, AG Kolmakov, MD Larionov, ME Prutskov, AS Alikhanyan, AV Samokhin, AS Lysenkov and DD Titov. Effect of sintering methods and temperatures on porosity of the ceramics from aluminum oxinitride. IOP Conf. Ser.: Mater. Sci. Eng. 2018; 347, 012030.

[53] G Dutta and D Bose. Effect of sintering temperature on density, porosity and hardness of a powder metallurgy component. Int. J. Emerging Technol. Adv. Eng. 2012; 2, 121-3.

[54] CS Obayi, R Tolouei, A Mostavan, C Paternoster, S Turgeon, BA Okorie, DO Obikwelu and D Mantovani. Effect of grain sizes on mechanical properties and biodegradation behavior of pure iron for cardiovascular stent application. Biomatter 2016; 6, e959874. 